\title{
KARAKTERISTIK KEFIR SUSU SAPI DENGAN INOKULUM RAGI TAPE
}

\author{
Characteristics Of Kefir Milk with Inoculum Ragi Tape
}

\author{
Rosmaida La Sinurat, Christina Nugroho Ekowati, Sumardi, Salman Farisi
}

\author{
Departement of Biology, Faculty of Mathematics and Natural Sciences, Lampung University \\ Jl. Prof. Dr. Soemantri Brodjonegoro No. 1 Bandar Lampung 35145 \\ E-mail: ecoli.lacto@gmail.com
}

\begin{abstract}
Kefir is a fermented milk product that has the typical flavours (acids and alcohol) and its processed by a number of microbes which include lactic acid bacteria $(L A B)$ and yeasts.The aims of this study were to know the character of the population of lactic acid bacteria (LAB), a population of yeasts, and chemical characters among others total acid, $\mathrm{pH}$ and alcohol levels in kefir milk with inoculum ragi tape. The population of $L A B$ and the population of yeast were calculated with the method of calculation of Total Plate Count. The levels of total acid titration method were determined by the acid. Acidity was measured using a pH meter and alcohol levels were determined by the method of Conway Micro Diffusion. The results showed that the number of LAB has increased to 24 hour fermentations of $9.01 \mathrm{log} \mathrm{cells} / \mathrm{ml}\left(1,1 \times 10^{9}\right.$ cells $/ \mathrm{ml}$ ), then the number of cells did not change much until the fermentation time was 48 hours and 72 hours of fermentation on the decline of $8.07 \mathrm{log}$ cells $/ \mathrm{ml}\left(1,2 \times 10^{8} \mathrm{cells} / \mathrm{ml}\right)$ while the yeast experiences increased from 6 hours to 24 hours, then the amount of yeast did not much change from the 24 to 72 hours of the highest number of yeasts during fermentation 48 hours an amount of $6.12 \mathrm{log} \mathrm{cells} / \mathrm{ml}\left(1,3 \times 10^{6}\right.$ cells $/ \mathrm{ml}$ ) and the amount of yeasts did not decline at the time of 72 hours. Total acid continued to experience increased with the number of 0.38-1.24\%, pH continued to decline from 6,47-4.27 and alcohol levels continued to experience increased with the number of $0.05-0.38 \% \mathrm{~b} / \mathrm{v}$.
\end{abstract}

Keywords: Inoculum, Kefir Milk, Lactic Acid Bacteria, Ragi Tape, Yeast

\section{PENDAHULUAN}

Kefir merupakan produk olahan susu yang difermentasi oleh sejumlah mikroba yang meliputi bakteri penghasil asam laktat (BAL), bakteri penghasil asam asetat, dan khamir (Aristya et al., 2013). Pada umumnya kefir susu dibuat dengan susu yang ditambahkan bibit kefir. Spesies mikroorganisme dalam bibit kefir di antaranya Lactocococcus lactis, Lactobasillus acidophilus, Lactobasillus kefir, Lactobasillus kefirgranum, dan Lactobasillus parakefir yang berfungsi dalam pembentukan asam laktat dari laktosa. Lactobasillus kefiranofaciens sebagai pembentuk lendir (matriks butiran kefir), Leuconostoc sp. membentuk diasetil dari sitrat, dan Candida kefir pembentuk etanol dan karbondioksida dari laktosa. Selain itu juga ditemukan Lactobassilus brevis, dan khamir (Torulopsis holmii danSaccharomyces) (Ide, 2008).

Menurut penelitian Sujaya et al. (2002) pada ragi tape terdapat bakteri asam laktat (BAL) antara lain Pediococcus pentosaceus, Enterococcus faecium, L. curvatus, Weissella confusa, dan Weissella paramesenteroides yang mampu membentuk asam laktat dari laktosa, selain itu juga terdapat khamir Saccharomyces.

Mikroorganisme pada ragi tape mampu memanfaatkan laktosa pada susu sapi. Laktosa berperan sebagai sumber nutrisi utama yang digunakan BAL. Laktosa akan dihidrolisis menjadi glukosa dan galaktosa dengan bantuan enzim laktase (Nelson et al., 2008). Menurut Wijaningsih (2008), pada proses fermentasi anaerob, khamir memecah glukosa menjadi alkohol dan karbondioksida.

Hasil dari fermentasi tergantung pada berbagai faktor, yaitu jenis bahan pangan (substrat), macam mikroba dan kondisi di sekelilingnya yang mempengaruhi pertumbuhan dan metabolisme mikroba tersebut. Mikroba yang bersifat fermentatif dapat mengubah karbohidrat dan turunan-turunannya terutama menjadi alkohol, asam dan $\mathrm{CO}_{2}$ (Madigan, 2013). Perubahan lingkungan dapat mengakibatkan perubahan sifat morfologi dan fisiologi mikroba. Dengan mengetahui mikroorganisme pada ragi tape, maka ragi tersebut dapat digunakan sebagai inokulum untuk pembuatan kefir. Oleh karena itu, karakter kefir dengan inokulum ragi tape menarik untuk diteliti. 


\section{METERI DAN METODE}

\section{Materi}

Alat yang digunakan adalah cawan Petri, labu Erlenmeyer, labu ukur, rak tabung reaksi, tabung reaksi, pipet volumetri, pipet tetes, autoklaf, oven, laminar air flow, Micro Conway Diffusion spektrofotometer, kalium bikromat asam sulfat, vortex, timbangan analitik, penangas air, gelas ukur, inkubator, orbital shaker, lemari pendingin, buret, lampu spiritus, hot plate, kapas, korek api, aluminium foil, kertas label, gunting, spidol, tabel alkohol,dan bulb. Bahan yang digunakan adalah isolat ragi yang diambil dari prodak kemasan, media de Man Ragosa and Sharpe Agar (MRSA), Potato Dextrose Agar (PDA), alkohol, aquades, susu sapi murni, $\mathrm{NaOH}$, phenolphthalein, $\mathrm{K}_{2} \mathrm{CO}_{3}, \quad \mathrm{~K}_{2} \mathrm{Cr}_{2} \mathrm{O}_{7}, \quad$ kalium bikromat jenuh, dan vaselin.

\section{Metode}

Penelitian disusun dalam percobaan dengan metode eksperimental.

Tahapan dalam penelitian ini yaitu:

1. Fermentasi Kefir

Sebanyak $100 \mathrm{ml}$ susu sapi dan ragi tape sebanyak 1 gr atau $1 \%$ dari volume susu dimasukan ke Erlenmeyer $250 \mathrm{ml}$ steril (Ernawati, 1996). Pengamatan dilakukan pada inkubasi 0 jam, 6, 12, 24, 48 dan 72 jam. Pengocokan dilakukan selama 10 menit pada orbital shaker dengan kecepatan 100 rpm pada inkubasi 24, 48, dan 72 jam.

\section{Penentuan Total BAL}

Penentuan total BAL dilakukan dengan menggunakan metode hitungan cawan (Total Plate Count). Pengenceran yang digunakan adalah $10^{-5} 10^{-6}, 10^{-7}$. Masing-masing diambil sebanyak $1 \mathrm{ml}$ sampel kemudian dipindahkan ke dalam cawan petri. Medium de Man Ragosa and Sharpe Agar (MRSA) steril yang ditambahkan $\mathrm{CaCO}_{3}$ sebanyak $1 \%$ dimasukkan ke cawan petri. Kemudian media dan suspensi diratakan dengan menggoyangkan cawan (metode pour plate). Lalu inkubasi selama 24 jam pada suhu $37^{\circ} \mathrm{C}$. Kemudian dilakukan penghitungan jumlah koloni (Hidayati, 2011).

\section{Penentuan Total Khamir}

Media yang digunakan adalah PDA (Potato Dextrose Agar) dengan antibiotik streptomycin sebanyak $1 \%$. Pengenceran yang digunakan adalah $10^{-3}, 10^{-4}, 10^{-5}$. Masingmasing diambil sebanyak $1 \mathrm{ml}$ sampel kemudian dipindahkan ke dalam cawan petri. Sebanyak $15 \mathrm{ml}$ media PDA ditambahkan ke dalam cawan petri. Inkubasi dilakukan pada suhu ruang selama 48 jam. Kemudian dilakukan pengamatan dengan menghitung jumlah koloni (Fardiaz, 1993).

\section{Penentuan Total Asam}

Susu ditimbang dalam Erlenmeyer sebanyak 18 gr, lalu ditambahkan 0,5 (10 tetes) phenolpthalein $1 \%$ sebagai indikator. Kemudian dilakukan titrasi dengan $\mathrm{NaOH}$ $0,1 \mathrm{~N}$ sambil dikocok sampai terbentuk warna merah muda yang stabil. Setelah itu pemakaian titer dicatat dan asiditas susu dihitung sebagai persen asam (Underwood, 1989).

\section{Pengukuran $\mathrm{pH}$ (Sudarmadji, 1997)}

Pengukuran $\mathrm{pH}$ dengan menggunakan $\mathrm{pH}$ meter.

6. Analisis Kadar Alkohol dengan Metode Micro Conway Diffusion

Sebanyak $1 \mathrm{ml}$ larutan kalium bikromat asam sulfat dimasukkan pada bagian tengah cawan. Kemudian $1 \mathrm{ml}$ sampel dan $1 \mathrm{ml}$ kalium bikromat jenuh dimasukan secara terpisah pada bagian tepi cawan. Cawan ditutup dengan hati-hati dan dirapatkan dengan vaselin. Lalu cawan digoyangkan dengan perlahan sehingga sampel dan larutan kalium karbonat jenuh tercampur dengan baik. Setelah tercampur biarkan selama 1-2 jam dan amati perubahan warna pada larutan kalium bikromat asam sulfat pada bagian tengah cawan. Larutan kalium bikarbonat diambil dengan mikropipet, diusahakan semua larutan terambil. Kemudian larutan dimasukan ke dalam labu takar $10 \mathrm{ml}$ dan diencerkan sampai tanda batas. Absorbansinya diamati menggunakan spektrofotometer pada $\lambda=480$ nm.

\section{HASIL DAN PEMBAHASAN}

Susu sapi yang diinokulasi dengan ragi tape mengalami perubahan secara mikrobiologi dan biokimia. Peningkatan populasi menunjukkan BAL ragi tape mampu menggunakan susu sapi sebagai substrat untuk metabolisme. Berdasarkan hasil perhitungan menunjukkan bahwa terjadi perubahan jumlah BAL dan khamir.

Pada fermentasi 0 jam jumlah populasi BAL pada penelitian ini sebesar 7,10 log sel/ml $\left(1,2 \times 10^{7} \mathrm{sel} / \mathrm{ml}\right)$ sedangkan jumlah BAL pada fermentasi 0 jam pada kefir susu sapi pada peneitian Tiska et al. (2011) yaitu sebesar 7,11 log $\mathrm{sel} / \mathrm{ml}\left(1,3 \times 10^{7} \mathrm{sel} / \mathrm{ml}\right)$. Hal ini menunjukkan kedua penelitian memiliki hasil yang tidak jauh 
berbeda. Populasi BAL kefir susu sapi pada fermentasi 12 jam adalah 8,16 log sel $/ \mathrm{ml}\left(1,4 \times 10^{8}\right.$ $\mathrm{sel} / \mathrm{ml})$. Jumlah populasi BAL dari penelitian ini lebih tinggi jika dibandingkan dengan yogurtsusu sapi dari penelitian Rahmawati (2015) dengan jumlah $7 \mathrm{log} \mathrm{sel} / \mathrm{ml}\left(1,0 \times 10^{7} \mathrm{sel} / \mathrm{ml}\right)$. Populasi BAL kefir susu sapi pada waktu fermentasi 24 jam adalah 9,01 log sel/ml $\left(1,1 \times 10^{9} \mathrm{sel} / \mathrm{ml}\right)$. Jumlah populasi BAL dari penelitian ini lebih tinggi jika dibandingkan dengan kefir susu sapi dari penelitian Yusriah dan Agustini (2014) dengan jumlah $7,11 \mathrm{log} \mathrm{sel} / \mathrm{ml}\left(1,3 \times 10^{7} \mathrm{sel} / \mathrm{ml}\right)$. Populasi BAL kefir susu sapi pada waktu fermentasi 48 jam adalah $1,2 \times 10^{9} \mathrm{sel} / \mathrm{ml}$. Jumlah populasi BAL dari penelitian ini lebih rendah jika dibandingkan dengan dadih susu sapi dari penelitian Afriani et al. (2011) dengan jumlah $0,33 \times 10^{11}-3,38 \times 10^{11}$ $\mathrm{sel} / \mathrm{ml}$. Pada fermentasi 72 jam jumlah populasi BAL sebesar $8,07 \mathrm{log} \mathrm{sel} / \mathrm{ml}\left(1,2 \times 10^{8} \mathrm{sel} / \mathrm{ml}\right)$.
Jumlah populasi BAL dari penelitian ini lebih tinggi jika dibandingkan dengan kefir susu sapi dari penelitian Yusriah dan Agustini (2014) pada fermentasi 72 jam dengan konsentrasi starter bibit kefir 3\% pada kefir susu sapi yaitu sebesar 6,74 $\log \mathrm{sel} / \mathrm{ml}\left(5,5 \times 10^{6} \mathrm{sel} / \mathrm{ml}\right)$.

Sunarlim (2009) yang menyatakan bahwa komponen yang paling berperan selama proses fermentasi bakteri asam laktat adalah laktosa. Laktosa merupakan molekul gula yang terbentuk dari dua molekul monosakarida (disakarida). Laktosa akan dihidrolisis menjadi glukosa dan galaktosa dengan bantuan enzim laktase, setelah menjadi monosakarida selanjutnya akan dimanfaatkan oleh BAL diteruskan ke fase glikolisis yang produk akhirnya, akan menghasilkan asam laktat yang berlangsung secara anaerob (Nelson et al., 2008).
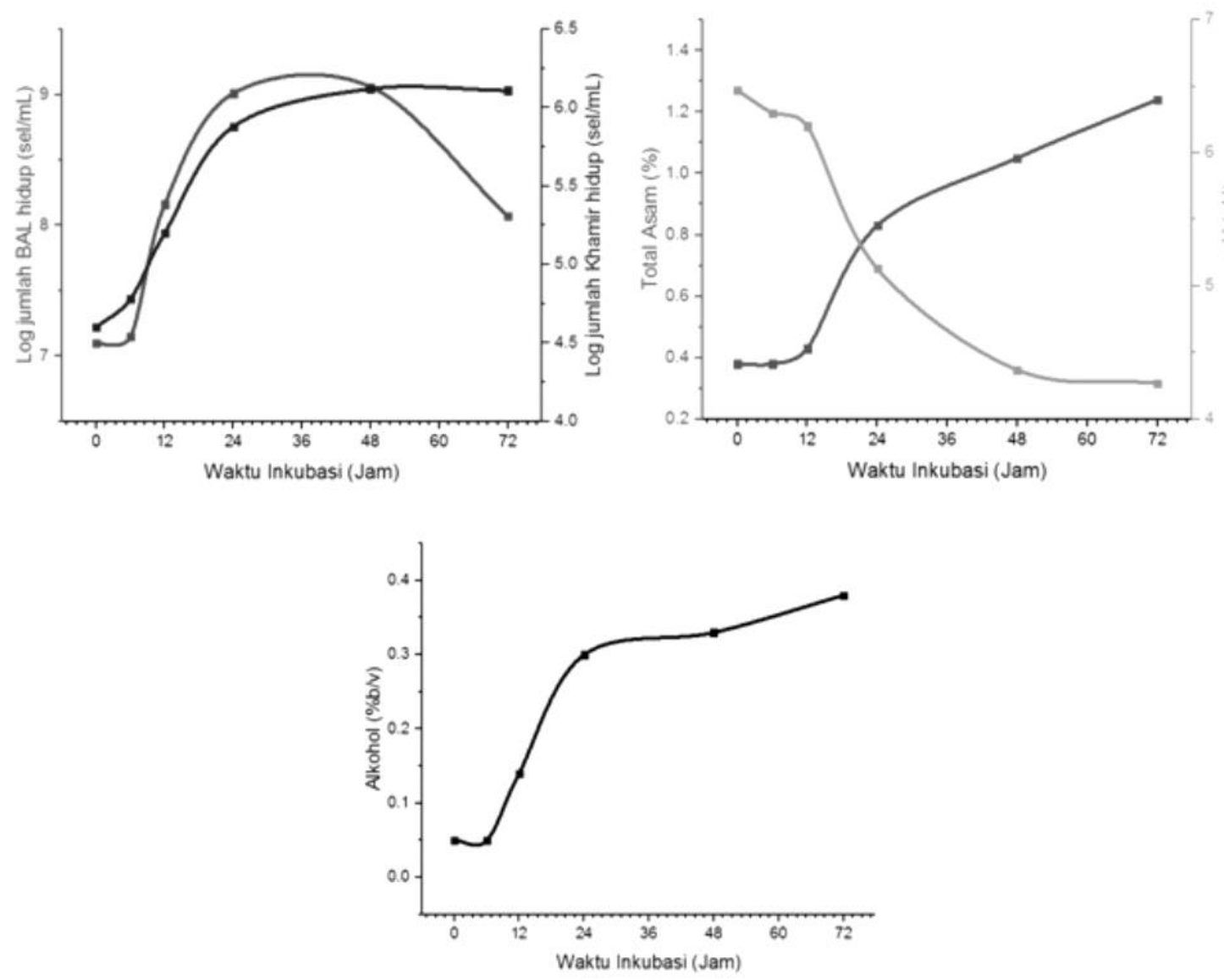

Gambar 1. Pengaruh Lama Fermentasi Kefir terhadap Pertumbuhan BAL, Pertumbuhan Khamir, Total Asam, pH dan Kadar Alkohol 
Khamir yang tumbuh pada media menggunakan glukosa untuk glikolisis. Setelah tahapan glikolisis kondisi fermentasi masih dalam keadaan aerob, maka asam piruvat akan diubah dalam tahapan dekarboksilasi oksidatif dan dilanjutkan pada tahapan siklus krebs yang menghasilkan banyak energi yang digunakan untuk sistem kerja sel, sintesis organel sel dan untuk membentuk generasi baru (Kim dan Gadd, 2008). Namun, jika kondisi fermentasi berubah menjadi anaerob maka asam piruvat tidak akan mengalami dekarboksilasi oksidatif, melainkan dirubah menjadi $\mathrm{CO}_{2}$ dan asetaldehid yang kemudian dirombak menjadi alkohol dan energi dalam jumlah yang lebih kecil (Draphco et al., 2008).

Produksi asam dikontrol oleh bakteri, sedangkan khamir memproduksi alkohol (Jay et al., 2005). Total asam adalah jumlah asam yang terbentuk selama proses fermentasi dari hasil pemecahan laktosa oleh BAL (Magalhaes et al., 2011). Total asam pada fermentasi kefir susu sapi dengan inokulum ragi tape menunjukkan peningkatan dengan jumlah 0,38-1,24\%. $\mathrm{PH}$ adalah ukuran konsentrasi ion hidrogen dari larutan.Pengukuran $\mathrm{pH}$ (potensial hidrogen) akan mengungkapkan jika larutan bersifat asam atau alkali (atau basa).Menurut Sadler and Murphy (2003), asam yang terukur oleh alat $\mathrm{pH}$ meter adalah konsentrasi ion $\mathrm{H}^{+}$yang terlepas. Pada penelitian kefir susu sapi dengan inokulum ragi tape didapatkan hasil total asam yang terus meningkat yang berarti meningkat pula ion $\mathrm{H}^{+}$ sehingga menyebabkan turunnya $\mathrm{pH}$. Pada jam ke 6 dan $12 \mathrm{pH}$ mengalami sedikit penurunan kemudian pada jam ke-24, 48 dan $72 \mathrm{pH}$ mengalami penurunan drastis (Gambar 1).

BAL mampu bersaing dengan bakteri lain dalam proses fermentasi alami karena memiliki ketahanan terhadap $\mathrm{pH}$ yang tinggi sampai rendah. Lactobacillus tumbuh optimum pada $\mathrm{pH}$ 5,8-6,6 (Ballows et al., 1991). Pada waktu fermentasi 6 sampai 24 jam $\mathrm{pH}$ kefir sebesar 5,13-6,30 sedangkan total asam sebesar 0,380,83\%. Menurut Winarno dan Fernandes (2007), pertumbuhan mikroba pada susu berhubungan dengan jumlah total asam. BAL dapat tumbuh dengan optimal pada kondisi total asam $<2,5 \%$. Pertumbuhan cepat yang terjadi pada khamir berpengaruh terhadap hasil kadar alkohol yang meningkat dengan jumlah $0,05-0,30 \% \mathrm{~b} / \mathrm{v}$ (Gambar 1).

Pada fermentasi jam ke 24 sampai jam ke 48 terjadi kompetisi antara BAL dan khamir pada kefir susu sapi dengan inokulum ragi tape (Gambar 1). BAL dan khamir menggunakan substrat yang sama yaitu glukosa, hal ini menyebabkan terjadi kompetisi untuk mendapatkan nutrisi. Selama pertumbuhan, BAL menghasilkan asam laktat yang menyebabkan $\mathrm{pH}$ terus menurun dan kondisi ini menyebabkan lingkungan yang kurang cocok untuk BAL sedangkan kondisi lingkungan yang asam mendukung pertumbuhan khamir. Pada fermentasi 24 sampai 48 jam total asam 0,83 1,05\% dan $\mathrm{pH}$ sebesar 5,13 - 4,37 (Gambar 1).

Dalam fermentasi kefir susu sapi dengan inokulum ragi tape, jenis bakteri yang digunakan adalah bakteri homofermentatif. Bakteri homofermentatif tidak menghasilkan alkohol sehingga tidak tahan terhadap akumulasi alkohol yang dihasilkan oleh khamir sehingga menyebabkan penurunan jumlah BAL. Pada jam ke 24 sampai 72 ini jumlah kadar alkohol 0,30$0,38 \% \mathrm{~b} / \mathrm{v}$. Terjadi penurunan jumlah BAL pada waktu inkubasi 48 sampai 72 jam, hal ini disebabkan oleh terjadinya kompetisi antara BAL dan khamir untuk mendapatkan nutrisi. Kemudian akumulasi alkohol yang dihasilkan khamir menyebabkan kerusakan pada dinding sel bakteri.Bakteri asam laktat termasuk dalam tipe gram positif yang mempunyai dinding sel tebal yang tersusun dari lapisan peptidoglikan yang terdiri atas protein, asam teikoat dan polisakarida serta bagian luar dikelilingi oleh lapisan sulfur protein (Delcour et al., 1999). Asam teikoat dalam dinding sel yang bermuatan negatif akan bereaksi dengan alkohol yang ada pada media sehingga menyebabkan dehidrasi pada dinding sel. Dehidrasi menyebabkan pori-pori mengecil dan terjadi penurunan permeabilitas dinding sel (Fardiaz, 1992).

Menurut Codex (2003) standar komposisi kefir susu yaitu BAL minimal $7 \log \mathrm{sel} / \mathrm{ml}\left(10^{7}\right.$ $\mathrm{sel} / \mathrm{ml})$, khamir minimal $4 \mathrm{log} \mathrm{sel} / \mathrm{ml}\left(10^{4} \mathrm{sel} / \mathrm{ml}\right)$, dan total asam minimal 0,6\%. Adams dan Moss (2008) bahwa kandungan alkohol yang memiliki kefir bervariasi antara $0,01 \%$ dan $1 \%$. Fermentasi kefir pada umumnya terjadi selama 24 jam. Pada penelitian ini, setelah inkubasi 24 jam jumlah BAL 9,01 log $\mathrm{sel} / \mathrm{ml}\left(1,1 \times 10^{9} \mathrm{sel} / \mathrm{ml}\right)$, jumlah khamir 5,88 log sel/ml $\left(8,9 \times 10^{5} \mathrm{sel} / \mathrm{ml}\right)$, total asam $0,83 \%$ dan kadar alkohol $0,30 \%$. Kefir susu sapi dengan inokulum ragi tape memenuhi seluruh standar komposisi.

\section{SIMPULAN}

Karakter kefir selama 72 jam fermentasi yakni sebagai berikut jumlah BAL mengalami peningkatan hingga pada fermentasi 24 jam sebesar 9,01 log sel/ml $\left(1,1 \times 10^{9} \mathrm{sel} / \mathrm{ml}\right)$, sampai 48 jam inkubasi tidak banyak mengalami perubahan. Selanjutnya populasinya menurun pada 72 jam fermentasi dengan jumlah sel sebesar $8,07 \log \mathrm{sel} / \mathrm{ml}\left(1,2 \times 10^{8} \mathrm{sel} / \mathrm{ml}\right)$. Jumlah khamir 
mengalami peningkatan hingga pada fermentasi 24 jam sebesar 5,88 log sel $/ \mathrm{ml}\left(8,9 \times 10^{5} \mathrm{sel} / \mathrm{ml}\right)$, sampai 72 jam inkubasi tidak mengalami perubahan. Total asam mengalami peningkatan dengan jumlah $1,24 \%$, $\mathrm{pH}$ mengalami penurunan 4,27, kadar alkohol mengalami peningkatan dengan jumlah $0,38 \% \mathrm{~b} / \mathrm{v}$.

\section{DAFTAR PUSTAKA}

Adams, M.R. dan M.O. Moss. 2008. Food Microbiology $3^{\text {rd }}$ ed. The Royal Society of Chemistry Publishing. United Kingdom.

Afriani, Suryono dan H. Lukman. 2011. Karakteristik Dadih Susu Sapi Hasil Fermentasi Beberapa Starter Bakteri Asam Laktat yang diisolasi dari Dadih Asal Kabupaten Kerinci. Agrinak. 1 (1).

Aristya, A.L., A. M. Legowo dan Ahmad. 2013. Karakteristik Fisik, Kimia, dan Mikrobiologis Kefir Susu Kambing dengan Penambahan Jenis dan Konsentrasi Gula yang Berbeda. J. Apl.Tek.Pangan. 2(3).

Ballows, A., H.G. Truper, M. Dworkin, W. Harder and K. H Schleifer. 1991. The Prokaryotes.2nd.Edition, A handbook on the Biology of Bacteria Chapter 70.

Codex. 2003. Codex Standard for Fermented Milks: Codex STAN 243. FAO/WHO Food Standards. Codex Alimentarius Commission.

Draphco, C.M., N.P. Nhuan., and T.H. Walker. 2008. Biofuels Engineering Process Technology. The McGrawHill Companies, Inc. USA.

Ernawati. 1996. Fermentasi Susu Menggunakan Ragi Tape dan Biji Kefir Kering. Ilmu Produksi Ternak. Institut Pertanian Bogor.

Fadiaz, S. 1992. Mikrobiologi Pangan 1. PT Gramedia Pustaka Utama. Jakarta.

1993. Penuntun Praktikum Mikrobiologi Pangan. Jurusan Tekonologi Pangan dan Gizi, FATETA, IPB. Bogor

Hidayati, Darimiyya. 2011. Pola Pertumbuhan Bakteri Asam Laktat Selama Fermentasi Susu Kedelai. J. Tek.Hasil Pertanian 3(2): 72-76.

Ide, P. 2008. Health Secret of Kefir, Menguak Keajaiban Susu Asam untuk Penyembuhan Berbagai Penyakit. PT. Elex Media Kompotindo. Jakarta.

Jay, J. M, M. J. Loessner and G. A. Golden. 2005. Modern Food Microbiology. 7th ed. Springer. New York.

Kim, B.H., G.M. Gadd, 2008. Bacterial Physiology and Metabolism. Cambridge University Press. Cambridge.
Madigan, M.T., J.M. Martinko, and J. Parker. 2013. Biology of Microorganisms. 12 th ed. Prentice Hall International. New York.

Magalhães, K.T., G.V.M. Pereira, C.R. Campos, G. Dragone and R.F. Schwan. 2011. Brazilian Kefir: Structure, Microbial Communities and Chemical Composition. Bra. J. Microbiol. 42: 693-702.

Nelson, D.L. and M.M.Cox, 2008. Lehning Principles of Biochemistry. 5th Edition. W.H. Freeman and Company. New York.

Rahman, A., S. Fardiaz, W. P. Rahayu, Suliantari dan C. C. Nurwitri. 1992. Teknologi Fermentasi Susu. Pusat Antar Universitas Pangan dan Gizi. Institut Pertanian Bogor. Bogor

Rahmawati, E. 2015. Kadar Protein, pH dan Jumlah Bakteri Asam Laktat Yoghurt Susu Sapi dengan Variasi Penambahan Sari Daun Kelor dan Lama Fermentasi yang Berbeda. Skripsi. Fakultas Keguruan Dan Ilmu Pendidikan. Universitas Muhammadiyah Surakarta. Surakarta.

Sadler, G.D. and P.A. Murphy. 2003. pH and Titratable Acidity. Food Analysis Third Edition: Purdue University. West Lafayette. Indiana.

Sudarmadji, S., H. Bambang dan Suhardi. 1997. Prosedur Analisa Untuk Bahan Makanan dan Pertanian. Penerbit Angkasa. Bandung.

Sujaya, I. N., S. Amachi, K. Saito, A. Yokota,K. Asanoand F. Tomita. 2002. Specific Enumeration of Lactic Acid Bacteria in Ragi Tape by Colony Hibridization with Specific Oligonucleotide Probes. World J.Microbiol.and Biotech. 18: 263-270.

Sunarlim, R. 2009. Potensi Lactobacillus sp. Asal dadih sebagai starter pada pembuatan susu fermentasi khas Indonesia. Balai Teknologi Pascapanen Pertanian 5:69-76.

Tiska, F.B., A. Sustiyah dan A. N. Al-Baarri. 2011. Total Bakteri Asam Laktat, Nilai Ph, dan Adhesiveness Susu Bifidus Berbahan Baku Susu dari Peternakan yang Berbeda dengan Penambahan Ekstrak BuahBuahan Lokal. Fakultas Peternakan, Universitas Diponegoro. Semarang.

Underwood, A.L. 1989. Analisis Kimia Kuantitatif. Edisi ke-5. Penerbit Erlangga. Jakarta.

Wijaningsih, W. 2008. Aktivitas AntiBakteri In Vitro dan Sifat Kimia Kefir Susu Kacang Hijau (Vigna radiata) oleh Pengaruh Jumlah Starter dan Lama Fermentasi. Tesis. Universitas Diponegoro. Semarang. 
Winarno, F.G. dan I. E. Fernandez. 2007. Susu dan Produk Fermentasinya. Mbrio Press. Bogor
Yusriah, N. H. dan R.Agustini. 2014. Pengaruh Waktu Fermentasi dan Konsentrasi Bibit Kefir terhadap Mutu Kefir Susu Sapi. UNESA. J. Chemistry 3(2). 